\title{
DIVERSITY OF LANGUAGES AND CULTURES IN LITHUANIAN CITIES: THE CASE OF KAUNAS CITY
}

\section{Laura Čubajevaitè}

\begin{abstract}
The European Union language policy promotes multilingualism. To maintain such a policy it is necessary to investigate the usage of languages in different spheres of life, both in formal and informal environments. According to the data of the latest Census of Lithuanian Residents (2001), there are 115 nationalities living in Lithuania. The data also indicate which languages are considered to be native languages among different nationalities. However, it is not clear what languages are actually used at home. This paper presents the preliminary results of research carried out under the project "Language Use and Ethnic Identity in Lithuanian Cities”. This project aims at investigating languages used at home in the biggest Lithuanian cities to find out the language dominance, choice, preference and competence. The research data were selected by questioning 8 to 10 year old pupils in major Lithuanian cities: Vilnius, Kaunas and Klaipėda. The paper focuses on Kaunas city and discusses the answers of Kaunas' schoolchildren. The preliminary results reflect the tendencies of the real linguistic situation in the city.
\end{abstract}

Keywords: questionnaire, home language, language preference, language dominance, language competence, ethnic identity, Lithuanian, English, Russian

\section{Introduction}

The European Union language policy promotes multilingualism (CEC 2005). According to the European Convention of 2003, the "union shall respect any cultural, religious and linguistic diversity” (Baldauf, Kaplan 2006: 6). To maintain this EU policy, it is necessary for Lithuania as an EU member country to find out what the real linguistic situation is and what languages Lithuanian residents actually use. It is also important to investigate the real use of languages and/or their varieties in the public and private domains. 
According to the data of the latest Census of Lithuanian Residents (2001), there are 115 nationalities living in Lithuania (LGS 2001). The registration data show which languages are considered to be native languages, but as some researchers point out, "linguistic census data are unreliable" (Pienemann, Kessler 2007: 252). It is not clear what languages or language varieties are used at home either. Migration, which has been increasing for various reasons (economic, political, technological, etc.), has also had an impact on the linguistic situation in Lithuania (Maslauskaite, Stankūnienè 2007). Thus the linguistic situation needs more thorough investigation.

Since 2001 several studies have been conducted that partially explored the linguistic situation in Lithuania. In 2000, research on the adaptation of Lithuanian ethnic minorities was carried out; several questions focused on language issues as well (Kasatkina, Leončikas 2000). In 2006, refugees and their family needs in the Lithuanian Republic were studied; the research target groups were refugees residing in Kaunas and Klaipeda. The research also paid attention to problems related to knowledge of the Lithuanian language (Kuzmickaite 2006). In 2004, Vilnius city residents were questioned. One of the aims of the investigation was to find out the languages that Vilnius residents speak in public and private environments, in what languages they watch television programmes and listen to the radio, and what their attitude to languages is in general (Hogan-Brun, Ramonienè 2005). In 2007 a study called "Language at Work" was carried out. It aimed at clarifying the situation and finding out the main tendencies of language use in the business environment in Lithuania, as well as investigating employees' and employers' attitudes towards the Lithuanian language at work in the business sector ${ }^{1}$. In spite of these projects, there has not been any thorough research of the linguistic situation in Lithuania as a whole since 2001.

The paper is based on a preliminary analysis of the "Language Use and Ethnic Identity in Lithuanian Cities" project results. The project was initiated by the "Multilingual Cities Project" (further referred to as MCP). MCP served as a "good practice" example of how to survey large numbers of respondents and determine the existing linguistic situation. The project was organised by the European Cultural Foundation, coordinated by Babylon - the Centre for Studies of Multilingualism - at Tilburg University and carried out with scientists from the Netherlands and other countries participating. During the project quantitative surveys were carried out in Gothenburg, Hamburg, the Hague, Brussels, Lyon and Madrid. The project's target groups were schoolchildren aged 6 to 11. By questioning schoolchildren, the project team aimed to discover what language(s) were used at home and at school, what the level of knowledge of these languages was, and what the language choice, dominance and preference were (Extra, Yagmur 2004). Following the MCP experience and methodology, the "Baltic Language and Integration Network" (coordinated by Gabrielle Hogan-Brun, University of Bristol) partners initiated the "Baltic Multilingual Cities Project":

- in 2006 in Estonia, coordinator Mart Rannut, Tallinn University (some of the research results are discussed in Soll's (2006) article);

- in 2007 in Lithuania, coordinator Meilutè Ramoniené, Vilnius University;

- in Latvia this activity is still in the planning stages. 
The project, carried out in Lithuania from 2007-2009, is called "Language Use and Ethnic Identity in Lithuanian Cities". It aims at investigating and measuring the relation between the languages used in the biggest Lithuanian cities (Vilnius, Kaunas and Klaipeda) and their users' ethnic identity. One of the project's aims is to foresee the perspectives of maintaining and preserving ethnic identity. The project work will be done in two stages: a quantitative home language survey of children, and quantitative and qualitative surveys of adults. The objectives of the first project stage are as follows:

- to investigate what languages are used at home by residents (children and adults) of the major cities of Lithuania;

- to determine which languages (or their varieties) are dominant or subordinate;

- to find out language choice and vitality.

In this paper the preliminary results of the first stage of the project, that is, the home language survey of children, will be discussed.

\section{Data and research methods}

The target group were schoolchildren of 8 to 10 years old. Children of such age were selected for several reasons: similarly to the MCP, the project aimed at questioning young language users in order to find out the vitality of the languages used. Unlike the MCP, Lithuanian project partners surveyed eight-year-old children who are able to read and write so that they could fill out the questionnaires themselves. The target cities were the major Lithuanian cities: Vilnius, Kaunas and Klaipeda. The home language survey questionnaire was designed according to and following the principles of the MCP questionnaire. The questionnaire had to be short and clear, therefore it consisted of twenty questions in total. Table 1 gives an outline of the information sought by the home language survey questionnaire.

Table 1. Home language survey questionnaire

\begin{tabular}{|l|l|}
\hline $1-3$ & pupil information (name, age, sex) \\
\hline $4-6,17$ & school information (city, school name, language of instruction, languages taught at school) \\
\hline $7-9$ & birthplace information (the pupil, father, mother) \\
\hline 10 & ethnicity \\
\hline $11-12$ & language(s) used at home \\
\hline 13,15 & knowledge of language(s) (4 skills: understanding, speaking, reading, writing) \\
\hline 14 & language choice \\
\hline 16,18 & language preference \\
\hline $19-20$ & specific questions (preschool education, TV) \\
\hline
\end{tabular}

The respondents were guaranteed anonymity by statistically processing and generalising all research data. The first ten questions in the questionnaire were included for demographic information. In questions 7-9 a list of prespecified countries was provided. Birthplace and ethnicity information was included to find out the relationship between a language and ethnic identity. Question 10 also had a list of nationalities prespecified, according to the census statistics on nationalities in 
Lithuania. Which language is used at home with family members is very important for defining language vitality, language choice and linguistic attitudes, as these, as well as language ideology, are acquired by children in the family (Auer, Wei 2007). Specific questions were included in order to find out whether early and non-formal education is popular and effective in Lithuania. Again, a list of prespecified languages was provided in the questionnaire.

\section{Quantitative research in Kaunas}

During the home language survey, all educational institutions in Kaunas teaching pupils in the age range from eight to ten years were visited. These included secondary schools, primary schools and kindergartens (some kindergartens in Lithuania have primary education classes).

Table 2. The general number of educational institutions in Kaunas (Kaunas Municipality Education Department data) and the number of institutions that participated in the survey

\begin{tabular}{|l|l|}
\hline Total & Total in the survey \\
\hline 62 institutions & 60 institutions \\
\hline 10173 schoolchildren & 8479 schoolchildren \\
\hline
\end{tabular}

The Table 2 shows that the majority of Kaunas educational institutions participated in the survey, during which about $85 \%$ of the target schoolchildren were surveyed. It should be mentioned that the survey in Kaunas took place in February and March of 2008, thus a great number of schoolchildren were absent from schools due to illness. As a result, about $15 \%$ of pupils did not participate in the survey.

As for the final stage of this survey - the data of the quantitative research will be processed statistically (SPSS) at Tilburg University, the Netherlands. This paper discusses only the preliminary results that do reflect the main tendencies of the linguistic situation in Kaunas. The preliminary analysis of the paper is based on a sample of 1050 randomly selected schoolchildren's questionnaires.

While discussing the results we distinguish three successive age groups:

- $\quad$ children of 8 years old (N 350);

- $\quad$ children of 9 years old (N 350);

- children of 10 years old (N 350).

\section{Some facts about Kaunas}

This paper deals only with the home language survey in Kaunas city, therefore some basic demographic, historic and social facts about the city will be provided in this section. According to the Census of the Russian Empire of 1897, the demographic structure of Lithuanian cities was as follows: " $42.1 \%$ of the residents claimed that their native tongue was Yiddish, 24\% considered Polish as their native tongue, 21.5\% spoke one of the Slavic languages as their mother tongue and $7.8 \%$ of the residents claimed that Lithuanian was their mother tongue" (Aleksandravičius, Kulakauskas 1996: 232). It is worth mentioning that the only criterion for determining ethnic identity was the language a person spoke (Aleksandravičius, Kulakauskas 1996). Unfortunately, 
the book does not distinguish between different cities. In the twentieth century, "a coexistence of the Lithuanian, Polish, Russians, Yiddish and German languages in Kaunas" is mentioned (Janauskas 2003: 34). In the interwar period, Jewish, Polish, Russian and German minorities led an active political, social and cultural life in Kaunas. As for the linguistic diversity in Kaunas, the above minorities had schools taught in their native languages, press in their native languages, and they participated in various social, cultural, religious and political organizations (Kaubrys 2002). In the same century some signs of "the Lithuanianising process of cities" were noticed; these were rather "peacefully accepted by the minorities of Kaunas city" (Janauskas 2003: 50). Later historical conditions, such as the holocaust, social factors such as assimilation, or economic and geographical factors during the Soviet period, ensured that Kaunas city was mostly inhabited by Lithuanians as compared to the ethnic composition of Vilnius and Klaipeda (Kaubrys 2002, Nikžentaitis et al. 2004). According to the Municipality data of January 1, 2008, Kaunas is currently populated by 355550 residents. ${ }^{2}$ According to the Census of the Lithuanian Republic of 2001, the ethnic distribution of Kaunas residents is as follows in Table 3 (LGS 2001).

Table 3. The ethnic distribution of Kaunas residents

\begin{tabular}{|l|c|}
\hline Ethnicity & Percentage \\
\hline Lithuanian & $92.9 \%$ \\
\hline Russian & $4.4 \%$ \\
\hline Ukrainian & $0.5 \%$ \\
\hline Polish & $0.4 \%$ \\
\hline Belarusian & $0.3 \%$ \\
\hline Jewish & $0.1 \%$ \\
\hline Roma & $0.1 \%$ \\
\hline German & $0.1 \%$ \\
\hline Tatar & $0.05 \%$ \\
\hline Latvian & $0.05 \%$ \\
\hline other nationalities & $1.1 \%$ \\
\hline
\end{tabular}

These numbers in Table 3 show that nowadays Kaunas is a rather homogeneous city. $88 \%$ of its residents, when answering the Census question about the native language, claimed that they consider Lithuanian to be their mother tongue. Currently there is only one school where the language of instruction is not Lithuanian but Russian; by way of comparison, there are seven such schools in Klaipeda, a city inhabited by only 185936 residents. ${ }^{3}$

Kaunas, unlike Vilnius or Klaipeda, has a linguistically better integrated community of Russian speaking people, who are more proficient in Lithuanian. It should be noted that after the 1990 o in Kaunas, like in Lithuania in general, the number of Russian speaking residents has slightly decreased. Economic and social factors have increased the number of residents of other ethnicities in Kaunas (for example, American, Chinese, Kazakh, etc.). The increasing mobility, migration and international economy have influenced the linguistic situation throughout Europe, and Kaunas city is no exception (Extra, Gorter 2001).

Though the initial research hypothesis suggested that Kaunas was a linguistically homogeneous city, the real linguistic situation in present-day Kaunas has not

2 www.kaunas.lt (8.01.2008).

3 www.klaipeda.lt (8.01.2008) 
been documented by any scholarly research. In addition, the project organisers find it useful to compare the linguistic situation of Kaunas with that in the other big cities of Lithuania (Vilnius and Klaipeda), which are more culturally and linguistically diverse.

In the following sections of this paper, qualitative and quantitative analyses of the preliminary results of the research conducted in Kaunas will be discussed. The quantitative research provides the statistics and reflects the tendencies of the linguistic situation, while the qualitative research sometimes helps to determine the reasons of particular phenomena and children's choices.

\section{Qualitative analysis of preliminary results}

While qualitatively reviewing the questionnaire answers, it was noticed that errors related to information about the birthplace and languages were rather frequent. It was found that, at this age, children's perception of the following concepts is very different:

- city vs. country (specific vs. general);

- country vs. language.

Several things were revealed in the pupils' answers about their own or their parents' birthplace. For instance, to answer the question about the birthplace the pupils could either choose one of the countries provided in a prespecified list (for example, Lithuania, Russia, Poland, etc.), or indicate "other" and write in the name of a country not found in the list. There were pupils who marked "other" and wrote in the name of a Lithuanian city or region (for example, Šiauliai, Žemaitija). The prototype theory might be applicable to interpret such children's choices. According to this theory, when acquiring word meanings, children first acquire the essential concepts or prototypes and only later recognise the category element (Geeraerts 1989, Rosch 1975, 1977, 1978, Labov 1972). In this case the hierarchical order might be difficult to understand for children: they cannot yet perceive that the city of Šiauliai or the region of Žemaitija are part of Lithuania. It may also be the case that Kaunas schoolchildren, who live in a homogeneous Lithuanian society, are rarely exposed to the issue of being born somewhere other than in Lithuania. Most probably the specific terms (city or region) are more frequent in their daily discourse, as most people in the children's environment were probably born in Lithuania and the country name is simply not mentioned.

Another group of pupils, when answering the same question, indicated two countries (for example, Lithuania and Russia). There were pupils who did not indicate their own or their parents' birthplace at all. Some of them commented that their parents were divorced and therefore they did not know where one of the parents was born. Another explanation could be that the concept of birthplace is rather difficult for children to understand. It was noticed that nine-year-old pupils provided erroneous answers more often than eight or ten-year-olds. Pupils of eight years old did not indicate their own or their parents' birthplace more often than the older children.

To answer the question about what other foreign language a pupil would like to learn, children had a prespecified list of language names or some space to write in 
a language that was not listed. Some pupils chose "other" and wrote in the names of non-existing, imaginary or false languages. Below we provide the erroneous language examples:

(1) egiptiečiu (literally 'the language of Egyptians')

egiptu (lit. 'the language of Egypts')

arabu ir egiptiečiu (lit. 'Arab and Egyptian')

brazilu (lit. 'the language of Brazilians')

romènu (lit. 'the language of Romans')

meksikiečiu (lit. 'the language of Mexicans')

Atènu (lit. 'the language of Athens')

belgu (lit. 'the language of Belgians')

Britanijos (lit. 'the language of Britain')

Australijos (lit. 'the language of Australia')

Argentinos (lit. 'the language of Argentina')

Kinijos (lit. 'the language of China')

Kaunas

It was noticed that nine-year-old children provided erroneous answers related to languages more often than the eight or ten-year-olds. Thus in their answers we could see either the lack of knowledge of what language is spoken in one or the other country (for example, egiptu, egiptiečiu, meksikiečiu, belgu, Britanijos, etc.), or invention of nonexistent languages (for example, Atènu, Kaunas, romènu). It could also be suggested that the principle of analogy is applied when children form the name of a language of a certain country. For example, the language that people of Lithuania speak is lietuviu (lit. 'the language of Lithuanians'), thus the language that people of Mexico speak is meksikiečiu (lit. 'the language of Mexicans').

To sum up the results of the qualitative analysis of the survey, it could be noted that children found it rather difficult to understand such concepts as country, ethnicity and birthplace. During the survey it was observed that the question "What is your ethnicity?" was found much easier if paraphrased by the interviewer into "Who are you?" Though the concept of language is perceived by children of this age, they still found difficulties in indicating the names of languages spoken in other countries or in assessing the level of their own language competence. Therefore, they sometimes exaggerated or, more often, underestimated their skills. For example, they would mark that they cannot write Lithuanian even though it was their mother tongue and taught from the very first years of schooling.

\section{Quantitative analysis of preliminary survey results}

In this section the preliminary quantitative results will be provided. In this paper the focus is on several questions of the survey that show the tendencies of the linguistic situation in Kaunas. The answers to these questions provide information on what language is most often used at home, what language is most often used to communicate with family members, relatives, and best friends, and what other languages pupils can speak, understand, read and write. The issues of what languages children watch TV programmes in, and what languages they want to learn as foreign languages, will be briefly discussed. 
Almost all Kaunas primary and secondary education institutions are culturally and linguistically homogeneous. Therefore, the majority (almost 100\%) of pupils who participated in the survey claimed that they know the Lithuanian language and that they are of Lithuanian ethnicity. Another dominating language, as the research results reveal, is English. Figure 1 shows the percentage of pupils who claimed that they know English.

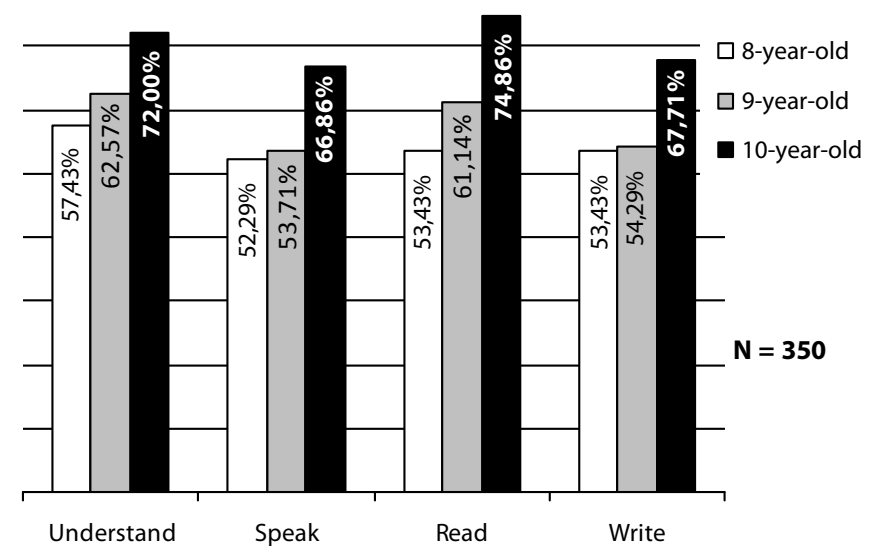

Figure 1. Knowledge of English by Kaunas schoolchildren

Figure 1 shows that more than $50 \%$ of 8 to 10 year old pupils indicated that they understand, speak, read and write in English. Ten-year-olds exceed the pupils of eight years old by $20 \%$ and the pupils of nine years old by $10 \%$ in all skills. A number of pupils indicated that they communicate with their best friends and watch TV programmes in English. Such a big number of pupils reporting to be actually using the language and willing to learn it, as was indicated in the questionnaire answers, shows that the English language is increasingly popular and vital. This has been the tendency in other European countries as well (Extra, Yagmur 2004).

One more language that was often mentioned in the pupils' answers is Russian. As shown in Figure 2, the number of respondents claiming that they know Russian was significantly smaller than those who know English.

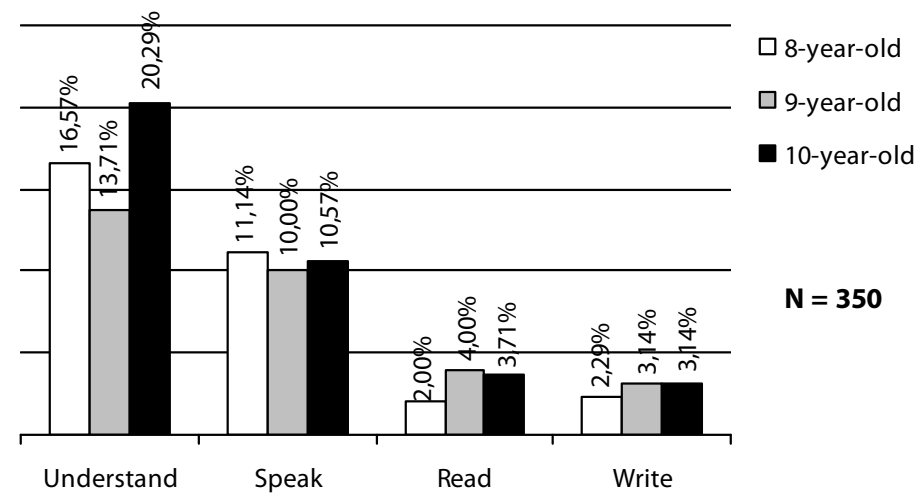

Figure 2. Knowledge of Russian by Kaunas schoolchildren 
Approximately $16.7 \%$ of Kaunas pupils claim that they understand the Russian language. The reason for the low number of pupils who know this language is the exclusion of Russian from the mandatory subjects in school curricula for the past years. A number of pupils claimed that they understand Russian a little. This might be explained by the fact that, according to the pupils, their parents switch to Russian when they want their children not to understand them. In addition, some children of Lithuanian ethnicity claimed that they speak Russian with their grandparents or watch TV programmes in this language, as in Lithuania some programmes from Russian TV channels are broadcast. Thus Russian is sometimes heard at home. In the survey a number of pupils indicated that they wanted to learn Russian as a foreign language. This shows an increasing need for and the vitality of this language.

A very small number (hardly 4\%) of pupils claimed that they know other languages (Russian, Latvian, Romani, Italian, Belarusian, Armenian, Yiddish, Ukrainian, German and Polish). Table 4 provides the number of pupils who mentioned that they know (understand, speak, read and write) languages other than Lithuanian and English.

Table 4. Knowledge of other languages at Kaunas schools

\begin{tabular}{|l|c|l|}
\hline Languages & Number of pupils & \multicolumn{1}{c|}{ Reasons } \\
\hline Latvian & 1 & Latvian ethnicity \\
\hline Romani & 3 & Roma ethnicity \\
\hline Italian & 2 & Not indicated \\
\hline Belarusian & 3 & $\begin{array}{l}\text { Mother born in Belarus, } \\
\text { Speaks Belarusian with grandparents }\end{array}$ \\
\hline Armenian & 1 & Mother born in Armenia \\
\hline Russian & 27 & $\begin{array}{l}\text { Mother born in Ukraine, } \\
\text { Father born in Armenia, } \\
\text { One of the parents born in Russia, } \\
\text { Speaks Russian with grandparents, } \\
\text { The pupil was born in Russia, } \\
\text { Russian language classes before school }\end{array}$ \\
\hline Yiddish & 1 & Father born in Israel \\
\hline Ukrainian & 2 & Not indicated \\
\hline German & 1 & Pre-school German classes \\
\hline Polish & 1 & Father born in Poland \\
\hline
\end{tabular}

As Table 4 makes clear, a very small number of pupils indicated that they know other languages. Out of the 1050 pupils randomly selected for this analysis, very few claim that they speak the languages indicated in Table 4. Russian is also included in the table because, unlike Figure 2, Table 4 shows the number of pupils who marked all four skills (understanding, speaking, reading, and writing) in this language. The most common reason why one or the other language mentioned in the Table 4 is spoken are ethnicity or family relations with speakers of the language; preschool education is mentioned very rarely. 


\section{Multilingualism in Kaunas}

Taking into consideration the facts discussed in previous sections, the question arises whether there are any examples of multilingual children in Kaunas. The only school in Kaunas where the language of instruction is Russian and not Lithuanian is the secondary school named after Alexander Pushkin. At the moment there are 105 pupils of 8 to 10 years old studying there (according to the Kaunas Municipality Education Department data of 2008). 85 pupils participated in the survey (see Table 5).

Table 5. The ethnic distribution of 8 to 10 year old pupils at Kaunas A. Pushkin school

\begin{tabular}{|l|c|}
\hline Ethnicity & Number of pupils \\
\hline Russian & 39 \\
\hline Lithuanian & 15 \\
\hline Chechen & 6 \\
\hline Ukrainian & 3 \\
\hline Armenian & 2 \\
\hline Azerbaijani & 1 \\
\hline Polish & 1 \\
\hline Jewish & 1 \\
\hline German & 1 \\
\hline
\end{tabular}

6 pupils indicated a double ethnicity (for example, Lithuanian-Russian or Lithuanian-Belarusian), whereas 9 pupils did not indicate any ethnicity at all. This shows again that the question as well as the very concept of ethnicity is rather difficult for children, especially for those from mixed families.

When answering the question what languages are used at home, the pupils mentioned Russian, Lithuanian, English and other languages. Figure 3 shows the distribution of the percentage of children who claim that they understand/speak/ $\mathrm{read} / \mathrm{write}$ one or the other language.

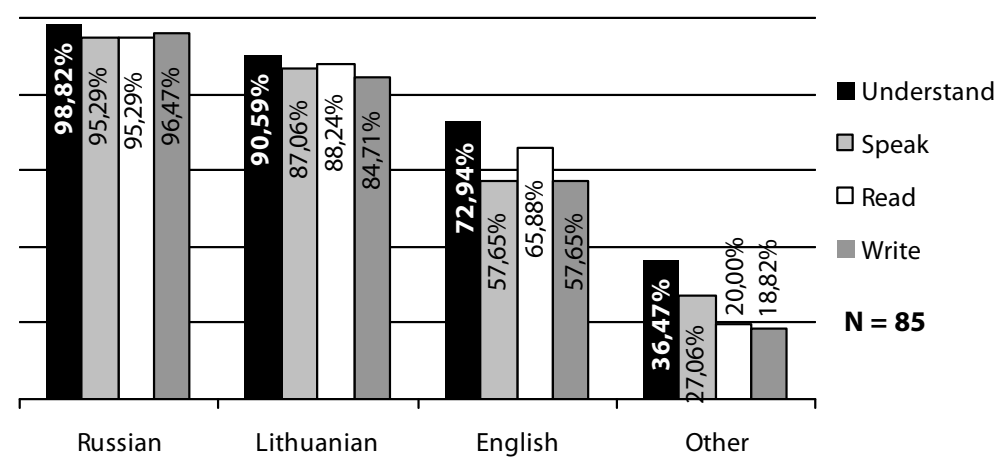

Figure 3. Knowledge of languages at the secondary school named after Alexander Pushkin

A similar percentage (about $96.46 \%$ and $87.65 \%$, respectively) of pupils mention that they know both the Russian and the Lithuanian language. The number of pupils claiming that they know English is a bit smaller, that is, about 63.53\%. In Figure 3 
"other" is most often the pupils' native tongues (Armenian, Belarusian, Chechen, Latvian, Spanish, German, Yiddish, etc.). Thus it could be claimed that students at this Kaunas school are multilingual as most of them are fluent in at least three languages (Auer, Wei 2007).

\section{Summary and conclusion}

The preliminary results of the research in Kaunas city proved the initial research hypothesis: Kaunas is a rather homogeneous city linguistically. Most Kaunas schoolchildren claim that they speak Lithuanian and that they are of Lithuanian ethnicity. The second language that is claimed to be known and used by Kaunas schoolchildren is English. Russian seems to be less popular and less widely used by Kaunas schoolchildren. Other languages used, such as Polish, Latvian, Romani, Italian, Belarusian, Armenian, Yiddish, Ukrainian and German are used by only a few of Kaunas schoolchildren. The main reason for using the other languages is parents' or grandparents' ethnicity; preschool education is mentioned very seldom. The Kaunas secondary school named after Alexander Pushkin is the place where most of the city's multilingual children study. The languages that these children claim to know are Russian, Lithuanian, English and, in most cases, their native languages.

The qualitative analysis of the preliminary results has shown that children find it rather difficult to understand such concepts as country, ethnicity and birthplace. Therefore, errors were made when answering these types of questions. It was observed that children from Pushkin school made more errors related to ethnicity than the schoolchildren from other Kaunas schools. This suggests that the concept of ethnicity is more confusing for children from mixed families. As for birthplace, Pushkin schoolchildren did not make errors as children from other Kaunas schools did. Most probably these issues are more common and clearer to children from mixed families.

It can be stated that more thorough and statistically processed results of this research could also be useful for comparison of the changing linguistic situation in Kaunas in a few years' time. The research results may be of importance to language policy makers and representatives of educational institutions, as they might suggest what languages need more promotion and what education and language policies are to be taken in the future.

\section{References}

Aleksandravičius, Egidijus; Kulakauskas, Antanas 1996. Carų valdžioje. XIX amžiaus Lietuva. Vilnius: Baltos lankos.

Auer, Peter; Wei, Li 2007. Introduction: Multilingualism as a problem? Monolingualism as a problem? - Auer, Peter; Wei, Li (Eds.). Handbook of Multilingualism and Multilingual Communication. Berlin: Mouton de Gruyter, 1-14.

Baldauf, B. Richard; Kaplan, B. Robert (Eds.) 2006. Language Planning and Policy in Europe: the Czech Republic, the European Union and Northern Ireland. Clevedon: Multilingual Matters.

CEC $2005=$ Commission of the European Communities 2005. Communication from the Commission to the Council, the European Parliament, the Economic and Social Committee and the Committee of the Regions. A New Framework Strategy for Multi- 
lingualism. COM(2005)596 final. http://ec.europa.eu/education/policies/lang/doc/ com596_en.pdf (20.12.2006).

Extra, Guus; Gorter, Durk (Eds.) 2001. The Other Languages of Europe: Demographic, Sociolinguistic and Educational Perspectives. Clevedon: Multilingual Matters.

Extra, Guus; Yagmur, Kutlay 2004. Urban Multilingualism In Europe: Immigrant Minority Languages At Home and School. Clevedon: Multilingual Matters.

Geeraerts, Dirk 1989. Introduction: Prospects and problems of prototype theory. - Linguistics, 27 (4), 587-612.

Hogan-Brun, Gabrielle; Ramonienè, Meilutè 2005. The language situation in Lithuania. Journal of Baltic Studies, 36 (3), 345-370. doi:10.1080/01629770500000131

Janauskas, Pranas 2003. Lietuviškasis lūžis. Kalbų varžybos Kauno savivaldybejje 1918-1928 metais. - Darbai ir Dienos, 34, 33-54. Kaunas: VDU.

Kasatkina, Natalija; Leončikas, Tadas 2000. Lietuvos etninių grupių adaptacijos kontekstas ir eiga. Tyrimo modelis. Vilnius: Eugrimas.

Kaubrys, Saulius 2002. National Minorities in Lithuania. Vilnius: Vaga.

Kaunas Municipality data. http://www.kaunas.lt (08.01.2008).

Klaipeda Municipality data. http://www.klaipeda.lt (08.01.2008).

Kuzmickaitè, Daiva 2006. Pabėgèlių ir jų šeimų poreikių Lietuvos Respublikoje tyrimo ataskaita. Kaunas: Socialinès ekonomikos institutas. http://209.85.135.104/search?q= cache:nJRVl85wuqEJ:www.lygus.lt/pabegeliai/files/Pabegeliu\%2520poreikiai_tyri mo\%2520ataskaita\%2520su\%2520log.doc+Projektas+\%22Kalba+darbe\%22\&hl=lt $\& c t=c \operatorname{lnk} \& c d=15 \& g l=l t$ (01.09.2008).

Labov, William 1972. Sociolinguistic Patterns. Philadelphia: University of Pennsylvania Press.

LGS 2001 = Lietuvos gyventojų surašymas 2001. Statistikos departamentas prie Lietuvos Respublikos Vyriausybès. www.stat.gov.lt (08.05.2008).

Lietuvos HSM duomenų archyvas. http://archive.lidata.eu/webview (31.08.2008).

Maslauskaitė, Aušra; Stankūnienė, Vlada 2007. Šeima abipus sienų. Lietuvos transnacionalinès šeimos genezė, funkcijos, raidos perspektyvos. Vilnius: Tarptautinė migracijos organizacija. Socialinių tyrimų institutas.

Nikžentaitis, Alvydas; Schreiner, Stefan; Staliūnas, Darius (Eds.) 2004. The Vanished World of Lithuanian Jews. New York: Rodopi.

Pienemann, Manfred; Kessler, Jörg-U. 2007. Measuring bilingualism. - Peter Auer, Li Wei (Eds.). Handbook of Multilingualism and Multilingual Communication. Berlin: Mouton de Gruyter, 247-275.

Rosch, Eleonor 1975. Cognitive reference points. - Cognitive Psychology, 7, 532-547. doi:10.1016/0010-0285(75)90021-3

Rosch, Eleonor 1977. Classification of real-world objects: Origins and representations in cognition. - P. N. Johnson-Laird, P. C. Wason (Eds.). Thinking: Readings in Cognitive Science. Cambridge: Cambridge University Press, 212-222.

Rosch, Eleonor 1978. Principles of categorization. - E. Rosch, B. Lloyd Barbara (Eds.). Cognition and Categorization. Hillsdale, NJ: Lawrence Erlbaum, 28-49.

Soll, Maie 2006. The language of instruction at primary school, ethnic involvement and national identity: The Estonian example. - Regioninès studijos, 2, 119-129. Kaunas: VDU.

Laura Čubajevaitė (Regional Studies Department, Vytautas Magnus University, Lithuania). Her research interests include foreign language teaching methodology and quality, second language acquisition, intercultural communication and multilingualism.

l.cubajevaite@trs.vdu.It 


\title{
KEELELINE JA KULTUURILINE MITMEKESISUS LEEDU LINNADES: KAUNAS
}

\author{
Laura Čubajevaitè \\ Vytautas Magnuse Ülikool
}

Euroopa Liidu keelepoliitika edendab mitmekeelsust. Selle poliitika toetamiseks vajab Leedu kui EL liikmesriik kõigepealt ülevaadet keelte kasutamisest eri elualadel, nii ametlikus kui mitteametlikus keskkonnas. Viimase rahvaloenduse andmeil (2001) elab Leedus 115 rahvuse esindajaid. Rahvaloenduse andmetest ilmneb ka, mis keeli eri rahvusest inimesed peavad emakeeleks. Siiski ei ole selge, mis keeli inimesed tegelikult kodus räägivad. Pärast 2001. aastat ei ole tehtud laialdasemaid uurimusi Leedu keelesituatsiooni kohta.

Artiklis esitatakse esialgsed tulemused uurimistööst, mis tehti projekti “Keelte kasutamine ja etniline identiteet Leedu linnades” raames. Projekti eesmärk oli selgitada suuremate Leedu linnade kodudes kõneldavad keeled: mis keeled domineerivad, mis keeli veel kasutatakse ja mis on keele valiku põhjused. Uurimuse andmed saadi 8-10-aastaste õpilaste küsitlemisel suuremates Leedu linnades: Vilniuses, Kaunases ja Klaipėdas. Artikkel keskendub Kaunasele, mida on alati peetud eriti rahvuslikuks linnaks: $88 \%$ elanikest nimetavad oma emakeelena leedu keelt. Artikkel tutvustab Kaunases tehtud uuringut ning analüüsib Kaunase õpilaste vastuseid.

Esialgsed tulemused näitavad tendentse tegelikus keelesituatsioonis. Enamik Kaunases küsitletud õpilasi väidab, et nad kõnelevad/mõistavad/loevad/kirjutavad leedu keelt, mis on nende emakeel. Teine keel, mida lapsed kasutavad, on inglise keel. Vene keele kasutus pole kuigi lai. Uuringu põhjal on ainsaks mitmekeelsuse saareks Kaunases Aleksander Puškini keskkool. Artiklis on lähemalt kirjeldatud selle kooli õpilaste rahvuslikku jaotumist ja keelekasutust.

Võtmesõnad: küsitlus, kodune keel, keele-eelistus, keele domineerimine, keelepädevus, etniline identiteet, leedu keel, inglise keel, vene keel 